\title{
Alcohol Septal Ablation of Hyperthropic Obstructive Cardiomyopathy Patient with Respiratory Failure
}

\author{
Jusup Endang, Haryadi, Siska Suridanda, Andika S, Roy Christian, Irmalita, \\ Sunu Budi Raharjo,Yoga Yuniadi
}

Departement of Cardiology and Vascular Medicine, Faculty of Medicine University of Indonesia, and National Cardiovascular Center Harapan Kita, Jakarta
Hypertrophic Obstructive Cardiomyopathy (HOCM) prevalence is about I among $\mathbf{5 0 0}$ population. It is caused by genetic malformation. Dyspnoe, angina pectoris and syncope are clinical manisfestation. Pharmacological and non-pharmacological treatments can be performed to relieve the obstructive symptoms. Recently alcohol septal ablation has been proven improve haemodynamic and functional status.

We report a case of HOCM patient with refractory lung oedema and intubated due to respiratory failure that was immediatelly improved afterseptal ablation.

(J Kardiol Indones. 20। 3;34:35-42)

Keywords: hypertrophic obstructive cardiomyopathy, acute lung oedema, septal ablation 
Jurnal

Kardiologi Indonesia

J Kardiol Indones. 2013;34:35-42

ISSN 0I 26/3773

\title{
Ablasi Septal pada Pasien dengan Hypertrophic Obstructive Cardiomyopathy pada Pasien dengan Gagal Nafas
}

\author{
Jusup Endang, Haryadi, Siska Suridanda, Andika S, Roy Christian, Irmalita, \\ Sunu Budhi Raharjo,Yoga Yuniadi
}

\begin{abstract}
Prevalensi kardiomiopati hipertrofi obstruktif (HOCM) sekitar 1 di antara 500 orang dalam populasi. Keadaan ini disebabkan oleh malformasi genetik. Gejala klinis dapat berupa dispnu, angina pektoris bahkan pingsan. Terapi farmakologis dan non-farmakologis dapat diberikan untuk tatalaksana obstruksi jalan keluar ventrikel kiri. Belakangan ini ablasi septal dengan alkohol telah terbukti memperbaiki status hemodinamik dan fungsional. Akan dilaporkan sebuah kasus HCOM dengan gagal jantung refrakter dan terintubasi akibat gagal nafas yang segera membaik setelah dilakukan ablasi septal alkohol.
\end{abstract}

(J Kardiol Indones. 2013;34:35-42)

Kata kunci: hipertrofi obstruktif kardiomiopati, edema paru akut, septal ablas



ipertrofi obstruktif kardiomiopati (HOCM) merupakan kelainan malformasi genetik yang cukup sering dijumpai dengan perkiraan prevalensi mencapai 1 dari 500 populasi. ${ }^{1}$ Yang mana kelainan ini akan membawa pada gejala sesak nafas, angina dan sinkop yang menyerupai penyakit jantung koroner. Pengobatan untuk menghilangkan tanda obstruksi

\section{Alamat Korespondensi:}

Dr. dr. Yoga Yuniadi, SpJP. Departemen Kardiologi dan Kedokteran Vaskular FKUI, dan Pusat Jantung Nasional Harapan Kita, Jln S Parman Kav 87 Jakarta I |420. E-mail: yogay136@gmail.com meliputi beta bloker dan calsium-channel blocker, ${ }^{2}$ atau dengan teknik pembedahan dari septum yang akan meredakan gejala. ${ }^{3}$ Walaupun teknik pembedahan menghasilkan perbaikan gejala pada banyak kasus, namun juga berkaitan dengan angka morbiditas dan mortalitas yang cukup signifikan. Akhir - akhir ini dikembangkan ablasi septal dengan bantuan ekokardiografi yang dapat memberikan ketepatan lokasi ablasi dan dapat memperbaiki hemodinamik dan fungsional pasien.

Data di Pusat Jantung Nasional Harapan Kita mencatat 52 pasien terdiagnosa dengan HOCM mulai dari tahun 2009 hingga Juli 2012. 


\section{Tujuan Presentasi}

Tujuan dari presentasi ini adalah untuk melaporkan kasus hipertrofi obstruktif kardiomiopati dengan edema paru akut yang ditatalaksana ablasi septal

\section{llustrasi Kasus}

Seorang pria 61 tahun datang ke unit gawat darurat pusat jantung nasional harapan kita pada tanggal 15 July 2012 dengan keluhan sesak nafas disertai dada terasa berat sejak 2.5 jam sebelum masuk rumah sakit, saat sedang membawa mobil, durasi lebih dari 20 menit disertai keringat dingin. Pasien juga mengeluhkan sesak nafas yang tidak berkurang dengan istirahat, dan merasa mual. Pasien lalu minum 1 tablet furosemid dan diltiazem $30 \mathrm{mg}$, namun keluhan tidak membaik. Pasien lalu dibawa ke UGD.

Pasien pertama kali datang ke poliklinik Rumah Sakit Pusat Jantung Nasional Harapan Kita (PJNHK) pada bulan juli tahun 2005 dengan keluhan sesak nafas dan dada terasa berat, didiagnosa angina pada hipertensi. Namun pasien tidak kontrol dan minum obat secara teratur. Sudah 4 bulan pasien tidak kontrol ke poliklinik. Selama di poliklinik pasien mendapatkan pengobatan lisinopril $1 \times 10 \mathrm{mg}$, bisoprolol 1x10mg, metformin $1 \times 500 \mathrm{mg}$, asam asetilsalisilat $1 \times 100 \mathrm{mg}$, furosemide $1 \times 40 \mathrm{mg}$, dan spironolakton $1 \times 50 \mathrm{mg}$. Pasien memiliki faktor risiko penyakit jantung koroner hipertensi, dislipidemia, riwayat keluarga dengan penyakit jantung koroner (PJK) dan perokok. Pasien pernah menjalani kateterisasi tahun 2005 dan 2009 dan dinyatakan normal koroner.

Pada pemeriksaan fisik didapatkan kesadaran kompos mentis, dengan tekanan darah 135/83 mmHg, denyut jantung $84 \mathrm{x} /$ menit, laju pernafasan $48 \mathrm{x} /$ menit dengan saturasi oksigen $93 \%$ dan afebris. Pada pemeriksaan fisik didapati murmur ejection sistolik 3/6 pada batas tepi kiri sternum (LLSB) dan murmur pan sistolik 3/6 di apex sementara pemeriksaan lainnya dalam batas normal. EKG menunjukkan irama sinus dengan QRS rate 84 kali per menit, aksis QRS normal, gelombang P mitral, Interval PR 0.18 detik, durasi komplek QRS 0.08 detik, dengan ST depresi I, avL, V5-V6, T inverted I, aVL, V5-V6, LVH (+).

Pemeriksaan laboratorium menunjukkan kadar haemoglobin $17.2 \mathrm{gr} / \mathrm{dl}$, hematokrit 51\%, leukosit 12670 /ul, ureum $29 \mathrm{mg} / \mathrm{dl}$, level kreatinin $0.82 \mathrm{mg} / \mathrm{dl}$, gula darah sewaktu $153 \mathrm{mg} / \mathrm{dl}$, natrium $137 \mathrm{mmol} / \mathrm{l}$, kalium $3.5 \mathrm{mmol} / \mathrm{l}$, kalsium total $2.23 \mathrm{mmol} / \mathrm{l}$, dan klorida $108 \mathrm{mmol} / \mathrm{l}$. Enzim jantung menunjukkan nilai CKMB 28 dan Troponin T 0.127.

Pemeriksaan foto thoraks menunjukkan rasio jantun ${ }_{\xi}^{-}$-thoraks sebesar 52\%. Segmen Aorta Elongasi dan segmen pulmonal normal dengan apex jantung downward dan pinggang jantung mendatar, disertai dengan tanda-tanda kongesti dan infiltrat (Gambar 1).

Pasien kemudian didiagnosa dengan NSTEMI TIMI skor 4/7 skor GRACE 280, edema paru akut, HOCM, dan Pneumonia Komunitas (CAP).

Saat di ruang emergensi pasien diberikan NTG hingga dosis $50 \mu \mathrm{g} / \mathrm{menit}$ dosis, furosemide $40 \mathrm{mg}$ (IV), Asam asetil salisilat $1 \times 100 \mathrm{mg}$, loading clopidogrel $300 \mathrm{mg}$ dilanjutkan $1 \times 75 \mathrm{mg}$, simvastatin $1 \times 20 \mathrm{mg}$,
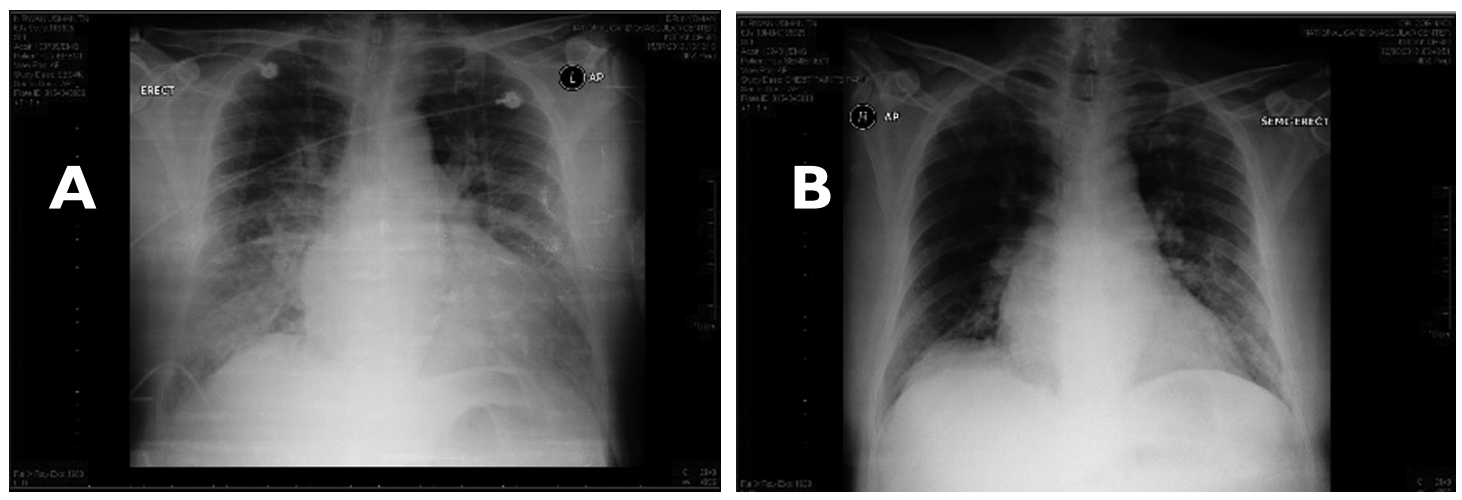

Gambar 1. Rontgen thoraks A. saat pasien masuk ke EMG PJNHK, B saat rawat jalan 
lisinopril 1x10mg, dilakukan heparinisasi setelah edema paru teratasi pasien kemudian dipindahkan ke ruang perawatan CVC.

Pada hari pertama sampai ketiga perawatan diruang intensif pasien mengalami episode edema paru akut berulang pada sindroma koroner akut berupa NSTEMI dan HOCM diberikan terapi isosorbit dinitrat intravena hingga $10 \mathrm{mg} / \mathrm{jam}$, perdipin intravena drip, metoprolol yang dilakukan penambahan dosis hingga 2x200mg serta CPAP untuk bantuan pernafasan didapati kesan dalam 3 hari perawatan dengan CPAP belum menunjukkan perbaikan dan edema paru belum teratasi. Dan evaluasi ekokardiografi dalam perawatan menunjukkan adanya $S A M$ (systolic anterior motion) dan dynamic gradient 140-190 mm Hg (Gambar 2).

Pada hari keempat perawatan, pasien dengan klinis sesak nafas on CPAP dengan tekanan darah 92/55 $\mathrm{mmHg}$, denyut nadi 99x/menit dan saturasi $\mathrm{O}_{2} 89 \%$, pasien kemudian diputuskan untuk dilakukan intubasi dan pemasangan ventilator.

Pada perawatan hari kelima hingga hari kesembilan, pasien dalam keadaan terintubasi didapati tekanan darah sistolik pasien cenderung rendah yaitu 80-90 $\mathrm{mmHg}$ dan laju denyut jantung 50-60 x/menit, pasien daalam kondisi tersedasi dengan midazolam $1 \mathrm{mg} / \mathrm{jam}$ dan terventilator dengan setting PRVC $\mathrm{FiO} 245-55 \%$, RR 10x/menit, PEEP 7, Tidal volume 640. Dalam perawatan dengan ventilator pasien tidak bisa dilakukan weaning ventilator serta gelisah bila terbangun. Dari pemeriksaan ekokardiografi memperlihatkan perbedaan tekanan subaortik 120 -
$140 \mathrm{mmHg}$. Pasien kemudian dilakukan penjadwalan untuk dilakukan ablasi septal.

Ablasi septal dilakukan dengan pemasangan alat pacu jantung sementara dan dilanjutkan dengan ablasi septal, dimana perbedaan gradient sistolik AoLV 80-110 mmHg. Hasil koroangiografi pre septal ablasi menunjukkan normal koroner. Dilakukan wiring ke cabang septal perforator kemudian di inflasi balon $2.0 / 20 \mathrm{~mm}$ pada proksimal septal yang dianggap memperdarahi area septum ventrikel. Kemudian dilakukan angiografi selektif melalui balon tidak tampak kolateral ke LAD. Kemudian dilakukan injeksi kontras 3cc dan dievaluasi ekokardiografi tampak kontras mengisi daerah septal. (Gambar 3) Kemudian dilakukan pemberian alkohol $96 \% 2 c c$ ke distal septal perforator dan balon tetap dalam posisi dikembangkan. Setelah 15 menit paska pemberian alkohol tampak LV-Ao gradient menurun hingga $32 \mathrm{mmHg}$.

Pada hari kedua paska ablasi septal kondisi klinis pasien perbaikan dan tidak menunjukkan adanya episode edema paru akut serta dilakukan weaning ventilator dan pasien berhasil di ekstubasi. Paska ekstubasi klinis pasien perbaikan dengan hemodinamik stabil pasien kemudian dipindah ke ruang intermediate. Evaluasi ekokardiografi didapati septal hipokinetik dan fraksi ejeksi paska tindakan 70\%.

Pasien dengan klinis perbaikan dan hemodinamik stabil di perbolehkan rawat jalan dengan evaluasi ekokardiografi menunjukkan perbedaan tekanan subaortik $15 \mathrm{mmHg}$.

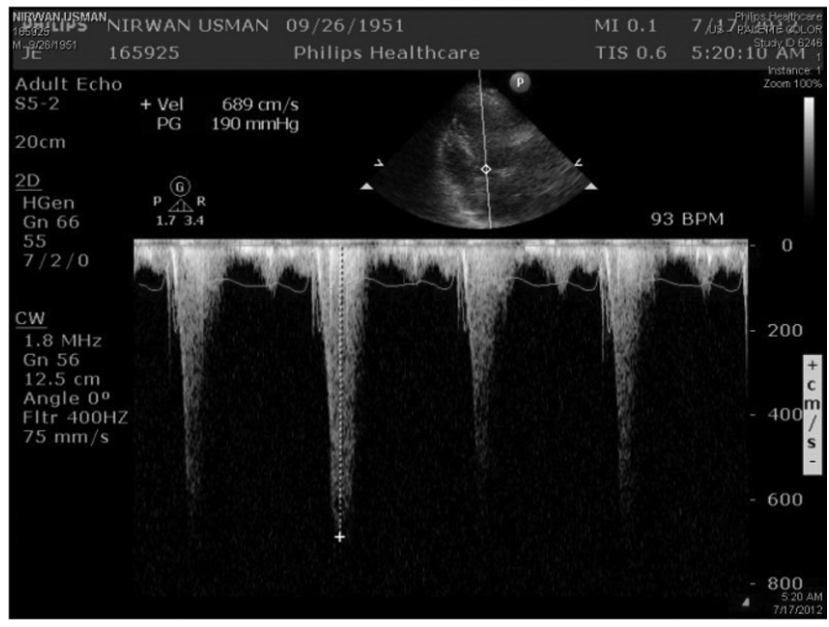

Gambar 2. Ekokardiografi sebelum Ablasi Septal A. Tampak SAM, B. Dynamic gradient

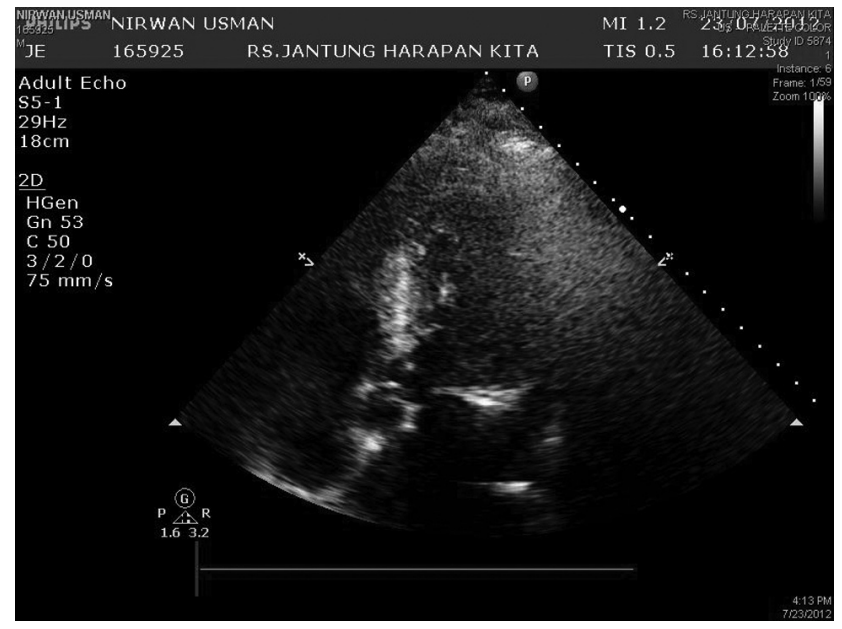

Gambar 3. Ekokardiografi menunjukkan kontras mengisi daerah septal 


\section{Tinjauan Pustaka dan Diskusi}

Hipertrofi kardiomiopati dikarakteristik sebagai penebalan tetapi tidak terjadi dilatasi ventrikel kiri dan tidak adanya kelainan jantung dan kondisi sistemik lainnya (contohnya stenosis katup aorta, hipertensi sistemik dan fisiologi jantung atlit).

Pada pasien ini didapatkan kelainan penebalan dinding jantung tanpa disertai adanya dilatasi ventrikel kiri dan tanpa adanya stenosis katup aorta.

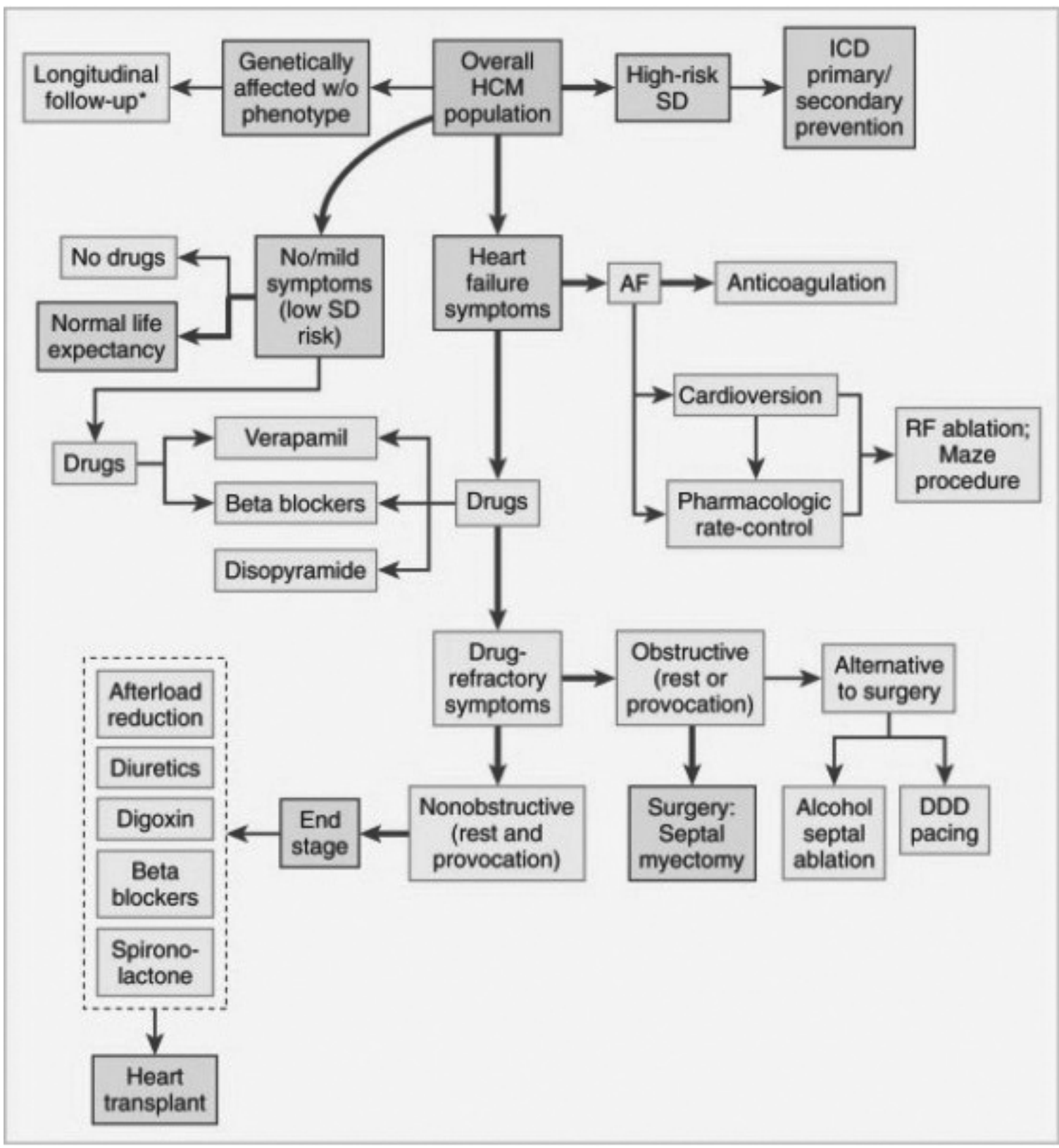

Gambar 4. Skema tatalaksana pasien dengan $\mathrm{HCM}^{4}$ 
Jurnal Kardiologi Indonesia

\section{Patofisiologi}

\section{Obstruksi outflow ventrikel kiri}

Obstruksi outflow ventrikel kiri jangka panjang (basal gradient $\geq 30 \mathrm{mmHg}$ ) merupakan faktor penentu yang kuat untuk hipertrofi kardiomiopati (HCM) yang berkaitan dengan progresifitas gejala gagal jantung dan kematian kardiovaskuler. ${ }^{4}$ Obstruksi subaortik pada HCM mewakili adanya tahanan mekanik terhadap outflow ventrikel kiri, yang mana secara langsung meningkatkan tekanan intraventrikular yang bersifat merusak fungsi ventrikel kiri dan dapat meningkatkan tekanan dinding ventrikel dan kebutuhan oksigen. Hal ini menyebabkan meningkatnya kadar troponin $\mathrm{T}$ dalam darah dan dikatakan bahwa semakin tinggi kadar troponin $\mathrm{T}$ menunjukkan semakin besarnya perbedaan tekanan subaortik dan ketebalan septal. ${ }^{5}$ Sebagian besar obstruksi terjadi akibat adanya systolic anterior motion (SAM) dari katup mitral dan kontak ventrikel saat midsistolik. ${ }^{4}$

Perbedaan tekanan subaortik (dan murmur ejeksi sistolik) pada HCM seringkali dinamik dengan variabilitas spontan dan menurun atau hilang dengan intervensi yang menyebabkan penurunan kontraktilitas miokard (betablocker) atau yang meningkatkan volume ventrikel atau tekanan arteri (jongkok, isometric handgrip, phenylephrine). Dan gradient dapat ditingkatkan dengan lingkungan yang menurunkan tekanan arteri dan volume ventrikel (spt. Manuver valsava, pemberian nitroglycerin atau amylnitrite, perdarahan, dehidrasi) atau meningkatkan kontraktilitas seperti kontraksi ventrikel prematur, infus isoproterenol atau dobutamin ataupun exercise. ${ }^{4}$

\section{Gejala klinis}

Gejala gagal jantung berkembang dan tidak bisa diprediksi, mulai dari sesak saat aktivitas hingga sesak saat berbaring dan sesak terbangun tengah malam. Sesak saat beraktifitas dapat disertai dengan keluhan nyeri dada. Kelainan lainnya berupa gangguan kesadaran seeperti sinkop ataupun rasa melayang yang diakibatkan aritmia ataupun obstruksi aliran keluar. Severitas gejala HCM tergantung pada adanya obstruksi outflow ventrikel kiri. ${ }^{6}$

Pada pasien ini didapati keluhan khas angina dan edema paru akut yang disebabkan oleh adanya perusakan fungsi ventrikel kiri, meningkatkan tekanan dinding ventrikel serta kebutuhan oksigen, sehingga terjadi iskemi miokard relatif yang juga menyebabkan peningkatan kadar troponin $\mathrm{T}$ dalam darah. Hal ini menyebabkan bias sehingga pasien didiagnosa sebagai NSTEMI dan edema paru akut. Pasien keluhan serupa pernah dilakukan kateterisasi dengan hasil normal koroner. Dari pemeriksaan ekokardiografi didapati perbedaan tekanan subaortik 140-190 mmHg dan terlihat adanya SAM dari katup mitral. Pasien tidak pernah terdokumentasi adanya sinkop dan gangguan irama jantung.

Pada pemeriksaan fisik didapati medium-pitch systolic ejection murmur pada sisi kiri bawah batas sternum dan apex yang bervariasi tergantung besar perbedaan tekanan subaortik. Pada pasien dengan derajat murmur sistolik 3/6 diperkirakan memiliki perbedaan tekanan outflow ventrikel kiri paling sedikit $30 \mathrm{mmHg} .{ }^{4}$

Dari pemeriksaan fisik didapati murmur ejeksi sistolik 3/6 pada sisi kiri batas bawah sternum dan pan sistolik murmur pada apex.

Pada elektrokardiografi memperlihatkan adanya LV hipertrofi, perubahan ST-T termasuk inversi gelombang $\mathrm{T}$ pada segmen lateral precordial, pembesaran atrium kiri, gelombang $Q$ yang dalam dan sempit serta hilangnya gelombang $\mathrm{R}$ pada segmen lateral precordial. ${ }^{7}$

Gambaran elektrokardiografi pada pasien ini juga menunjukkan adanya LV hipertrofi, $T$ inversi pada I, avL, V5 dan V6, pembesaran atrium kiri namun tidak terlihat adanya gelombang $Q$ pada segmen lateral precordial. Dengan keluhan khas angina disertai gambaran ekg serta troponin $\mathrm{T}$ yang meningkat mengecoh pemeriksa sehingga didiagnosa edema paru akut pada NSTEMI.

\section{Tatalaksana}

Gejala gagal jantung seperti sesak saat aktivitas dan nyeri dada yang merupakan akibat dari diastolik disfungsi, sumbatan aliran keluar ventrikel kiri hingga iskemik mikrovaskular miokard ataupun kombinasi berbagai patofisiologi. Sejak pertengahan tahun 1960 an, obat beta-adrenergic receptor blocking bermanfaat dalam memperbaiki gejala gagal jantung pada tipe HCM obstruksi maupun yang non obstruksi dengan menurunkan laju denyut jantung dan kontraksi ventrikel kiri yang mana dapat meningkatkan pengisian dan relaksasi ventrikel serta mengurangi kebutuh- 
an konsumsi oksigen. Skema tatalaksana HCM diperlihatkan pada Gambar 4.

Pasien ini dengan gejala gagal jantung akut disertai dada terasa berat yang mana pada awal diperkirakan suatu NSTEMI dengan edema paru akut diberikan terapi isosorbid dinitrat yang mana menurunkan tekanan arteri dan volume ventrikel hal ini memperberat kondisi pasien. Kemudian pasien diberikan metoprolol yang dilakukan penambahan dosis secara cepat yang diharapkan dapat menurunkan kontraktilitas miokard dan diharapkan dapat menurunkan perbedaan tekanan subaortik, namun dengan metoprolol $2 \times 100 \mathrm{mg}$ dan laju denyut jantung telah mencapai $60 \mathrm{x} /$ menit kondisi gagal jantung akut pasien masih belum teratasi sehingga diputuskan untuk stabilisasi dengan alat bantu nafas.

Obstruksi LVOT terjadi pada $20-30 \%$ pasien dengan HCM. Sejumlah pasien masih menunjukkan gejala walaupun telah mendapat optimal terapi. Dan penyelesaian dengan pembedahan biasanya direkomendasikan pada pasien ini. Namun suntikan ethanol intrakoroner (septal perforator) cukup popular pada pasien HOCM yang refrakter terhadap terapi.

Yuniadi dkk melaporkan untuk pertama kali di Indonesia keberhasilan menurunkan gradien tekanan trans-LVOT setelah dilakukan tindakan percutaneous transluminal septal myocardial ablation (PTSMA). Dengan bantuan kontras ekokardiografi untuk menentukan secara tepat target arteri septal lebih menjamin keberhasilan menurunkan gradien tekanan LVOT dengan kemungkinan komplikasi yang sangat kecil. ${ }^{8}$

Perbandingan keberhasilan septal ablasi dan pembedahan dalam menghilangkan LVOT obstruksi

Nagueh S.F dan Xin dkk mendapatkan bahwa terdapat persamaan penurunan ketebalan basal septal pada yang dilakukan pembedahan dan septal ablasi. ${ }^{8} 9$ Wllem G dkk (2005) terjadi penurunan obstruksi LVOT paska dilakukan septal ablasi dalam follow up 6 bln. ${ }^{11}$

\section{Pengaruh septal ablasi dan pembedahan pada} gejala dan toleransi olahraga

Pada pasien dengan septal ablasi dan pembedahan memiliki kesamaan NYHA class yaitu I dan II paska di lakukan tindakan. ${ }^{9,10}$
Pengaruh septal ablasi dan pembedahan pada fungsi dan ukuran ventrikel

Xin dkk menyatakan bahwa tidak ada perbedaan bermakna terhadap fungsi dan ukuran ventrikel pada pasien dengan septal ablasi maupun yang mendapat pembedahan. ${ }^{9}, 10$ Willem dkk menyatakan tidak ada perbedaan ukuran ventrikel yang bermakna paska dilakukan tindakan septal ablasi. ${ }^{11}$ Studi lainnya menyatakan bahwa tidak terdapat perbedaan bermakna baik fungsi maupun ukuran ventrikel paska dilakukan tindakan septal ablasi.

\section{Lama perawatan}

Pada pasien dengan septal ablasi didapati lama perawatan yang lebih singkat dibandingkan dengan pembedahan. ${ }^{9,10}$

Pasien ini merupakan pasien HCM dengan obstruksi, telah dikonfirmasi melalui ekokardiografi. Pasien menunjukkan gejala gagal jantung akut dan diberikan terapi metoprolol namun gagal jantung akut belum bisa teratasi. Berdasarkan skema tatalaksana (gambar 4) pasien direncanakan untuk tindakan operatif ataupun ablasi septal. Dengan mempertimbangkan risiko dan manfaat dari setiap tindakan. Dari berbagai literatur mengenai perbandingan keberhasilan septal ablasi dan pembedahan dalam menghilangkan obstruksi LVOT, Pengaruh septal ablasi dan pembedahan pada gejala dan toleransi olahraga, Pengaruh septal ablasi dan pembedahan pada fungsi dan ukuran ventrikel, serta lama perawatan dari kedua tindakan akhirnya diputuskan dilakukan tindakan septal ablasi dengan penuntun kontras ekokardiografi. Pasien kemudian telah dilakukan septal ablasi dan perbedaan gradien menunjukkan perbaikan dibandingkan semula. Dengan perbedaan gradien yang masih cukup tinggi $60 \mathrm{mmHg}$ pasien dapat dilakukan ekstubasi, klinis dan hemodinamik membaik. Pasien kemudian dilakukan evaluasi ekokardiografi didapatkan perbedaan tekanan subaortik $15 \mathrm{mmHg}$ dan diperbolehkan rawat jalan.

\section{Ringkasan}

Telah dilaporkan seorang laki-laki usia 61 tahun dengan edema paru akut pada HOCM, yang mana sebelumnya pasien ini terdiagnosis edema paru akut 
pada NSTEMI dan HOCM. Dalam perawatan, edema paru akut terjadi berulang sehingga dilakukan intubasi dan pemasangan ventilator. Dilakukan tatalaksana optimal medikamentosa, pasien belum menunjukkan perbaikan gejala.

Selanjutnya pasien dilakukan ablasi septal dengan penuntun kontras melalui penilaian ekokardiografi. Pre tindakan ablasi dilakukan corangiografi didapatkan hasil normal koroner. Paska tindakan, klinis pasien perbaikan dan edema paru akut teratasi. Dengan kondisi klinis dan hemodinamik stabil pasien diperbolehkan pulang.

\section{Daftar Pustaka}

1. Lakkis NM, Nagueh SF, Kleiman NS, et al. Echocardiographyguided ethanol septal reduction for hypertrophic obstructive cardiomyopathy. Circulation. Oct 27 1998;98(17):1750-1755.

2. Frank MJ, Abdulla AM, Canedo MI, Saylors RE. Long-term medical management of hypertrophic obstructive cardiomyopathy. Am J Cardiol. Dec 1978;42(6):993-1001.

3. Robbins RC, Stinson EB. Long-term results of left ventricular myotomy and myectomy for obstructive hypertrophic cardiomyopathy. J Thorac Cardiovasc Surg. Mar 1996;111(3):586-594.

4. Braunwald E. Braunwald's Heart Disease. In: Maron BJ, ed. Hyperthrophic Cardiomyopathy. Vol 2. 9 ed. philadelphia: Elsevier Saunders; 2012.

5. Sato Y, Taniguchi R, Nagai K, et al. Measurements of cardiac troponin $\mathrm{T}$ in patients with hypertrophic cardiomyopathy. Heart. Jun 2003;89(6):659-660.
6. Maron BJ, McKenna WJ, Danielson GK, et al. American College of Cardiology/European Society of Cardiology clinical expert consensus document on hypertrophic cardiomyopathy. A report of the American College of Cardiology Foundation Task Force on Clinical Expert Consensus Documents and the European Society of Cardiology Committee for Practice Guidelines. J Am Coll Cardiol. Nov 5 2003;42(9):1687-1713.

7. Maron BJ, Towbin JA, Thiene G, et al. Contemporary definitions and classification of the cardiomyopathies: an American Heart Association Scientific Statement from the Council on Clinical Cardiology, Heart Failure and Transplantation Committee; Quality of Care and Outcomes Research and Functional Genomics and Translational Biology Interdisciplinary Working Groups; and Council on Epidemiology and Prevention. Circulation. Apr 11 2006;113(14):1807-1816.

8. Yuniadi Y, Koencoro AS, Hanafy DA, Firman D, Soesanto AM, Segewiss H. Percutaneous transluminal septal myocardial ablation (PTSMA) for hypertrophic cardiomyopathy: Indonesian initial experience. Med J Indones. 2009;19:164-71.

9. Qin JX, Shiota T, Lever HM, et al. Outcome of patients with hypertrophic obstructive cardiomyopathy after percutaneous transluminal septal myocardial ablation and septal myectomy surgery. J Am Coll Cardiol. Dec 2001;38(7):1994-2000.

10. Nagueh SF, Ommen SR, Lakkis NM, et al. Comparison of ethanol septal reduction therapy with surgical myectomy for the treatment of hypertrophic obstructive cardiomyopathy. $J$ Am Coll Cardiol. Nov 15 2001;38(6):1701-1706.

11. van Dockum WG, Beek AM, ten Cate FJ, et al. Early onset and progression of left ventricular remodeling after alcohol septal ablation in hypertrophic obstructive cardiomyopathy. Circulation. May 17 2005;111(19):2503-2508. 